\title{
THE CHURCHES WERE OPENED AND LOTS OF MISSIONARIES ARRIVED: DIALOGUE BETWEEN KOMI IDENTITY AND FAITH
}

\author{
Art Leete, Piret Koosa
}

\begin{abstract}
The Komi people in northern Russia tend to consider the Russian Orthodox faith as a natural part of their lives and self-image. During recent decades different Protestant churches have spread intensively over the Republic of Komi. Although the Protestants constitute a small minority of the local population, they play a major role in initiating discussion concerning ethnic traditions, identity and the freedom to select a faith. The local population's predominant approach to religious issues is blurred, although they tend to prefer the Russian Orthodox faith, albeit without frequenting church ceremonies. This pro-Orthodox stand is grounded on loyalty to ancestors and ethnic traditions. We take the process of religious change among the Komis as a starting point from which to discuss issues of individual and collective identity, and the variability and stability of people's self-understanding as well as understanding of the Other.
\end{abstract}

Keywords: the Komis, Protestant, Russian Orthodox, individual identity, collective identity

\section{INTRODUCTION: IDENTITY AND FAITH'}

In this paper we analyse the way that social identity and religious issues are treated in a contemporary Komi village. ${ }^{2}$ We concentrate on the ideas concerning social categorisation documented by us over the last 16 years in a region ${ }^{3}$ that has to a certain extent been influenced by Protestant missions over the last decade.

It has been acknowledged among scholars that Pentecostal and charismatic (P/c) Christians advocate egalitarian identity discourse that emphasises the issue of being the children of God and the attempt to reduce the role of class, race, gender, traditions, and ethnicity in people's self-identification (see, for example, Robbins 2004: 125; Lunkin 2009: 92; Meyer 2010: 120-121).

At the same time, different studies also indicate that $\mathrm{P} / \mathrm{c}$ Christians' relationships with local customs and traditional ideology are more ambivalent. These 
missions propose certain egalitarian ideas but the aim is not to eliminate all previous, familiar differences (Robbins 2010: 637, 647-648; Meyer 2010: 121-122).

In the Komi case, we concentrate on a few examples that enable us to reveal how details of identity play a certain role in building up a model for the treatment of the religious domain. We provide as a starting point for our discussion local, culture-specific self-image of the Komis and then track some moments of dialogue between the traditional and P/c identity approach.

$\mathrm{P} / \mathrm{c}$ Christianity proposes an identity trend with a strong egalitarian emphasis. In a way, the Komis also favour sameness of the collective self. However, the Komis expect that the identification of an individual with a group must be associated with traditions and ethnicity. Proper religious belongingness (to Russian Orthodoxy) is part of the overall identity configuration, although it does not play a key role in it. And in contrast to the P/c demand for comprehensive believing, contemporary Komi folk Orthodoxy is much more fragmentary in everyday life.

It is justified to claim that the self is "plastic, variable and complex" and that its depiction must follow this "complexity" (Cohen 1995: 2). This variability is definitely easier to follow if we analyse individuals. The collective self is more levelled but to a certain extent and in specific conditions individuality also moves towards collectivism (see Hogg \& Reid 2006: 8-9).

The compelling requirement for a strong sense of self extends beyond individuals to groups, large and small. A sense of collective self may be qualitatively different from that of individual self, but the imperative need for identity is not less. (Cohen 1995: 11)

An individual perceives him- or herself differently as a person and as a member of a group. Nevertheless, the need for both identity dimensions is evident. Group norms reveal the specific properties of a group. Collective rules shape the group's behaviour, which, in turn, initiates diffusion and generates further regulations (Hogg \& Reid 2006: 7). Intergroup behaviour may promote different models of communication, for example, conflict, cooperation, and social change. An accent is put "on intergroup competition over status and prestige, and the motivational role of self-enhancement through positive social identity" (ibid.).

Michael Hogg and Scott Reid propose that individuals' understanding of group characteristics can be revealed by mapping a cognitive set of people's descriptions of features of their shared identity:

Individuals cognitively represent social categories as prototypes. These are fuzzy sets, not checklists, of attributes (e.g., attitudes and behaviours) that define one group and distinguish it from other groups. (ibid.: 10) 
We aim to discuss the relationship between social identity and religion in the Kulömdin district of the Republic of Komi, Russia, as it can be established in the contemporary situation. We attempt to combine the social identity approach that emphasises the entanglement of individual and group categories.

\section{KOMI IDENTITY (KULÖMDIN VERSION)}

Historically, since the 19th century, the Komis have been described as the children of nature, harsh, tough, hospitable, honest, simple, careless, uncultured, curious, talkative, smart, reasonable, creative, slow, etc. (Popov 1874: 47-52; Mikhailov 2010 [1851]: 23; 2010 [1852]; Arsenyev 2010 [1873]: 46; Volkov 2010 [1879]: 57, 62-63; see also Jääts 2005). These are typical scholarly statements of the time. In general, it was presupposed that indigenous ('primitive') people could be easily described as a group, because they share similar personality traits and in their simplicity they cannot hide their psychological essence. This meant that there was no recognised need to investigate individuals because they would not indicate anything specific.

Although today scholars pay much more attention to individual expressions of identity, it must be admitted that the Komis largely emphasise collective selfdetermination. Among the Kulömdin Komis, an idea exists of their being the very central and most common people (the biggest Komi ethnographic group, the most correct dialect).

There are a number of different dialects but it seems to me that we in Kulömdin have the most correct [dialect], [identical to] literary language. All our words correspond to literary language. In our village there are no deviations from the written language. (F, b. 1939, FM 2006)

Sometimes this centeredness is represented quite prominently:

We, the Upper Ezhva ones, assume that, firstly, we are the biggest group that speaks our native language. [If we secede,] there will be nothing. ${ }^{4}$ This people will disappear. ${ }^{5}$ (M, b. 1965, FM 2006)

Even the pastor of the local evangelical community (a Russian from Nizhniy Novgorod) admits: "Here in Kulömdin people say that they are chik komi mort. It means that they are the real Komi people, they speak the [real] Komi language." (M, b. 1978, FM 2009)

In traditional agrarian societies (and the village Komis belong to this category at least partly) people build up their self-image and social relations based on equalising and balance (see Stark 2002: 32-33). A number of interviews made 
during our fieldwork indicate that the Komis consider themselves as ordinary, average people who are characterised by all kinds of intermediate parameters. They represent the right and customary way of life. Individual behaviour and characteristics are connected to the representation of the group of village Komis as a whole. The self represents prevalent values and norms of a community.

Different qualities ascribed to the village community as a whole may not always actually hold true when it comes to individuals. Nevertheless, a person tends to define him- or herself drawing on those characteristics (Koosa 2010: 109).

\section{RELIGIOUS PRACTICE AND KOMI IDENTITY}

Orthodox Christianity has occupied a central place in the Komi culture for a long time. Relatively little is known about the pre-Christian beliefs and worldview. The first bishop of Komi, St Stephan of Perm (Stephan Khrap) had already converted the Komis to Russian Orthodoxy by the end of the 14th century. Stephan created the Old Permic alphabet called Anbur and translated ecclesiastical texts into the Komi language. The alphabet was used until the 17th century but it continues to have a strong symbolic meaning and encourages the understanding of the Komis as an especially Christian Finno-Ugric nation. Over the centuries Orthodox Christianity became an integrated part of the worldview and everyday life of the Komis (see, for example, Episkop Pitirim 1996; Chernetsov 1996; Vedernikova 1996; Limerov 2003: 63; Savelyeva 2004: 59-60; Zherebtsov \& Zherebtsov 2004: 211-212). Klavdiy Popov asserted that by the 19th century the Komis had became more religious than their "enlighteners", i.e., Russians (Popov 1874: 47). Today, the Orthodox religion is generally treated as the proper faith of the Komis.

In the Kulömdin region, the Russian Orthodox faith has been the dominant spiritual force since the 17th century, when the Komis inhabited the area. At the same time, it is significant that from the 18th century, the Upper Ezhva region was also one of the three centres of the Komi Old Believers (see Vlasova 2010: 18, 24-25). In addition to the local folk Orthodox movement, Bursylysyas ('singers of good' in Komi) have spread in the area since the end of the 19th century. ${ }^{6}$ In the Upper-Ezhva region the very first Protestant community in Komi lands appeared at the end of World War I (consisting of German war prisoners) (Sidorov 1997 [1928]). At least from the end of World War II, the Protestant communities have existed in the district continually (FM 2008).

Despite the overall long-term religious diversity in the Kulömdin region, most of the groups aside from mainline Orthodoxy have always been marginal. 
At least in a certain tacit manner, this being an average village Komi is related to (folk) Orthodoxy. Orthodoxy is also seen and valued as a meaningful framework for understanding the world by those people who do not actually consider themselves to be religious or believers. Religion is not usually seen by the village Komis as a special sphere of life. Rather, it is just one part of the knowledge and skills that constitute some kind of practical set of guidelines or regulations that people follow in their everyday lives (Koosa 2010: 109).

Such a relationship between faith and identity has been described as characteristic of different people in a global context:

[...] adherence to a common complex of beliefs offers practical benefits to a human group by giving it a common set of collective representations that enhances social cohesion. The performance of communal rituals strengthens bonds even more. (Hicks 1999: xx; see also Durkheim 1995 [1912]: 41)

Similarly to other regions of Russia, the Russian Orthodox Church (ROC) also attempts to restore its former positions in the Komi Republic. Local bishop Pitirim has declared:

Orthodoxy is the traditional religion of Komiland and we are going to fight out our canonical territory. European countries already went that way, defending historical Christian values from the fatal influence of alien religions and sects. We follow the European way and we are not afraid of anything. The Komi land has been blessed by St Stephan of Perm and we must carefully keep all treasures we have got from that superior historical and religious figure. (Episkop Pitirim 2010)

Several authors have referred to the contemporary spiritual environment as a "religious marketplace" in the sense that nowadays people can choose freely between different religions and consume their services as in a free market (see discussion, for example Gross 2008: 648; Panchenko 2004: 112; Shterin 2000: 178). This concept points to the issue that different religions compete for followers on equal grounds and the choice is made purely on the basis of individual preference. In fact, this concept may fit more to an urban environment. In rural areas, a social network dominated by relatives and neighbours is much tighter and communal social control is stronger. In this situation, it may appear more complicated to choose a 'strange' or 'non-traditional' faith as it may cause ridicule and condemnation. Even if a Komi does not consider him- or herself a believer in the strict sense of the word, Russian Orthodoxy is valued higher as the faith of the ancestors, as one's own faith. 
Local people curse me, my neighbour curses me. She says to me, well, why are you not in the Orthodoxy but in Christianity? ${ }^{7}$. Why do you believe in Christianity? [---] But I don't feel anything bad at the moment, everything is just fine. No evil stuff has been taught to us by anybody, despite the issue that we are engaged in the Christian faith. (F, b. 1938, FM 2008)

Most of the Komi villagers do not regard themselves as true believers. Possibly, clear spiritual self-definition is not an essential problem for the people who follow folk Orthodox practices and assure continuity of local religious traditions. This silent persistence helped to preserve the faith throughout the Soviet era. These folk Orthodox believers may express quite strong opposition to competing new religious groups. At the same time the possibility of finding new meanings and alternative understanding of the world is not entirely excluded. Most importantly, it is understood that everybody must have some kind of firm ground for interpreting the surrounding world (Koosa 2010: 47).

Of course it is better if a person believes, even if he is not [Russian] Orthodox Christian. Anyway, I don't have in mind those secret sects who turn people into zombies, demand complete submission and something else. I speak about Christian religions, different branches, about Christianity. I think that it is better to let a man believe, because a person must have some kind of undivided inner spiritual core. Without that spiritual core only physical substance remains. In this case, it is problematic to distinguish a man from an animal. (F, b. 1970, FM 2007)

Several visits to the Kulömdin Komis have revealed to us certain indicators that refer to the idea of commonness. People present themselves as ordinary and this is in a silent but deeply rooted way related to Russian Orthodox faith. It is simply self-evident, natural, that the village Komis are Russian Orthodox. Concurrently it is clear that even those who do not admit that they are believers regard Russian Orthodoxy as their own and meaningful way of looking at the world. In addition, these people are granted access to the knowledge of Russian Orthodox traditions and they use it for practical purposes. Faith of the Komis does not have a particular shape. It rather manifests itself in everyday activities and in daily communication in a way that Clifford Geertz refers to as a common sense (see Geertz 1993 [1983]: 73-93).

For a considerable time, the Old Believers and Bursylysyas movements have been organic elements of the local religious landscape. It has been argued that both groups have greatly influenced the character of the spiritual aspects of identity dynamics among the Kulömdin Komis. On the one hand, these movements constitute a conservative moment in local religiosity, while on the other hand, they formulate a certain loyalty to innovative and alternative religious 
trends. It is uncertain to what extent this line of discussion based on the logic of analogy has actually influenced the majority of the local population in their way of believing. The hegemonic position of proper Russian Orthodoxy is unquestioned in the area and people make a clear difference between the Old Believers and the usual Orthodoxy. The Bursylysyas' separation from the ROC is anyway ambivalent (see Koosa \& Leete 2011).

In the post-Soviet period, two tendencies have resulted from the ROC's attempts to restore its former position in society. The first tendency is connected to marginalisation of the majority of the Orthodox population in Komi villages, who do not always follow the official teaching or even consider it as privileged or essential when communicating with the divine and otherworldly. They represent a loose network of folk Orthodoxy with its members' faith manifested in unarticulated and hidden forms, where spiritual behaviour is not remarkably affected by the increase of public attention towards post-Soviet religious issues. These people's understanding of faith is framed by a certain feeling of continuity. For them, being a village Komi also means acceptance of folk Orthodoxy. They visit church only a few times a year during the major church holidays. Those practising the faith may be really skilled in traditional domestic religion and they preserved this through the Soviet period when there were no churches or priests available in the region. These people themselves stress that they are not really 'believers' because they lack the knowledge about accurate faith and the related know-how, stating: "The believers fasted but we lacked the skill so we did not fast!" For these people, the understanding of 'real believing' is related to frequent church-going and regular domestic prayers (Koosa 2010: 51; Leete 2011). In a way, then, the Kulömdin Komis accept the stance of the local Orthodox priest, who states that only a person who strictly follows the rules and teachings of the official Church and not some "suspicious" folk traditions can be considered truly Orthodox.

The second trend is related to the growing passion of churchgoers. The core of churchgoers is remarkably enthusiastic, having become dedicated believers during the last 15-20 years, and this group contains mainly middle-aged and elderly Komi women who enthusiastically attend church ceremonies, Sunday school, and other related social events, indicating that churchgoers' loyalty to their priest forms a significant part of their religious identity. In church they find strength to withstand difficulties, consolation and opportunity to share their experiences with other churchgoers (Koosa 2010: 53; Leete 2011):

Here can I find my remorse, my strength of mind, food - spiritual and physical. Beauty! You can also have a chat, here they understand you and you understand the others. (F, b. 1955, FM 2007) 
Actually, the borderline between these two groups is not clear. The churchgoers' group includes several 'grannies'8 who represent the other group which supports folk Orthodox traditions. They have not experienced spiritual awakening or conversion but continue to believe as they did during the Soviet period. Today they just attend church but prefer to stay in the background without active involvement in the congregation's activities (Koosa 2010: 51).

\section{PROTESTANTS AS 'THE AMERICANS'}

Although in Kulömdin district only few small groups of evangelical Christians have appeared, they are perceived as a considerably dangerous force by the local population (particularly, by the district's administration and local priests of the ROC). The activities of Protestant missions (that are all perceived as foreign, although some of them have a Russian origin) are interpreted through a presumed political agenda as an internal fifth-column activity with strategic objectives that involve imposing foreign power and culture (see also Koosa 2010: 46):

I don't know. I can't regard these [new Christian denominations] as trustworthy. I am very much intrigued to find out who stands behind that and from where they get resources. You see, that's the reason why I can't trust them. (F, b. 1970, FM 2007)

This kind of attitude from the Orthodox population is not unambiguous, as we can see from discussions between local people. However, clearly a strong element of suspicion is present.

F1 (b. 1965): The American here promotes ... of course, he says that everything is normal, about God, love. But I deny very much the fact that he is here.

F2 (b. 1960): He helps a lot. He has many things like that ...

F1: Listen! All this is American politics. Who would take him here if he didn't help as he does? I could understand if he comes here with an open heart. But we have lots of such 'Williams'9 here in Russia and it must be purely the result of American politics. (FM 2006)

In local disputes concerning the presence of Protestant groups in the area, a conceptual combination of the ethnic and religious Other can be detected. The most wide-spread ethnically based label for the Don village Protestants in the area 
is 'the Americans'. The reputation of the American factor in local religious life is reflected in the regional newspaper with a strong Russian Orthodox agenda:

- The Americans distribute their faith. They go to kindergartens and principals allow them to perform. All doors are open to them.

- Who are these Americans?

- Those who live in the neighbouring Don village. Of course, they do not go by themselves but their followers do. A woman from the district centre sends her preachers to us. They visit schools and give ten roubles to every pupil for the purpose that children would approach them later. They have been invited to kindergartens to participate in festal days. Once they were invited to celebrate a birthday. They held hands and started to pray in their own way. After that one woman got a headache and was suffering more than a week.

- I was shocked by this situation. The two Americans who have settled in Don village have converted the whole of Kulömdin district to their Protestant faith. At the same time there are plenty of our monks in Ulyanovo monastery ${ }^{10}$ and priests who inhabit the same region, but they are not able to resist the Americans at all. (Suvorov 2007)

Certainly, this approach is somewhat exaggerated, but it clearly shows the direction of the local population's attitude towards the Don evangelical community.

The American missionary William himself admits that his presence causes problems in communicating the Christian message to a wider social audience:

I'm not an organisation, OK? I'm one American; it's not like everybody ... When I first came here, everybody [said] - well, there are all the Americans, you know. There's only one. Lots of people will call you all kinds of names and it hurts being an American because - ha, American, he's a spy or he's here because he wants something, you know, that kind of ... persecution. (FM 2008)

Local members of the Don evangelical group reflect a lot on the issue that they are called 'the Americans'. In all cases it is done with a certain ironic standpoint. As an example we provide a short discussion developed by a couple of more experienced members of the group:

F1, b. 1966: We have one American, William, but all of us are referred to as the Americans. 'There are the Americans walking!' [laughing]

F2, b. 1971: They obey the American faith! [laughing]

F1: There is the American faith, consequently - all of them are Americans! 
F2: Although we became believers a long time before he arrived here. He got here to us and we were already believers. (FM 2009)

The pastor of the Don evangelical community explained the issue of a certain fear of America by specific historical circumstances:

There is a problem that if you are Protestant, you must be somehow ... You see, here we are all called 'the Americans'. All of us, even me - ah, the Americans! This is how they refer to us generally. All this is still present in people's mentality. For a long time people were just unaware of any religious plurality. They were not acquainted with the fact that a number of different regular Christian churches exist. Even during the Soviet years, the only church that people knew was the Orthodox church. And that was usually closed. A storehouse or a store was built in there. Later the churches were opened and lots of missionaries arrived, mostly Protestants. But people had preserved such a mentality that only one true church existed, the Orthodox Church. If you are a Russian, consequently you are an Orthodox. (M, b. 1978, FM 2009)

Don evangelicals are convinced of William's wonderful personality, with one of the core members of the group expressing how the group perceives the American missionary's character:

He does not try to convert the Orthodox people. People can see this and support him. He is an American. He just has a different kind of heart. You must believe that he does it all just because of love. You need to have that sort of heart that is filled with kindness and love and prayers to $\operatorname{God}^{11}$ (F, b. 1966, FM 2008)

This topic is much elaborated on among the Don evangelical community. The members of the group recognise that local people blame them for being too fond of foreign cultural and political influence. However, the evangelicals do not agree with this view, stressing several facts, such as the fact that three local people were members of the Baptist community of Syktyvkar even before the evangelical missionaries arrived in the area and also the simple point that they are not Americans but Komis and Russians. ${ }^{12}$ They also point out that in the context of religious freedom Protestant faith is legal in Russia and they have the right to follow it.

The circumstances are even more complicated because the local population in general considers the Russian Orthodox religion to be the proper faith because of its traditional position in the area. Being accused of attacking cultural traditions and foundations of society by their religious preference, the evangelicals 
attempt to argue that they are actually not opposed to the indigenous worldview but are themselves also a conventional part of local culture.

For example, bridging the Orthodox and evangelical worldviews is done by depicting the American missionary William as St Stephan of Perm, the christianiser of the Komis.

The enlightener is necessary. Just as Stephan of Perm arrived in Komiland and spread Christianity here, William arrived in the same way. When we first met in Syktyvkar, at the church of Christ the Saviour $^{13}$, he said that he had no idea where to move. At that time, in our Kulömdin district [in the Republic of Komi] we had the highest rate of unemployment, the highest level of criminality and addiction. William planned different social programmes to help elderly people and alcohol addicts. I told him that our district needed all this very much. And, in addition, also spiritual support, naturally. He told me that he needed to think about this and get advice from God. He must do as God commands. And after a month I was called and told that I had to find a residence for him. (F, b. 1966, FM 2008)

Identifying missionary William with St Stephan of Perm is related to an ideology that supports an interpretation of the history of evangelisation among the Komi people, which claims that in the 14th century St Stephan of Perm started missionising in the Komi language. Later, the Orthodox clergy gave up teaching in Komi. And today evangelical Protestants have re-established an indigenous mission, thus returning to the original evangelising practices of the first Komi missionary. In this way, Komi Protestants can make claims about authenticity. ${ }^{14}$

Nevertheless, it is clear that the topic of possible similarities between the missionary practices of St Stephan of Perm and contemporary Protestants is too complicated to be used in everyday situations when the evangelicals need to argue their indigeneity or 'not-otherness'. To explain their domestication, Protestants often claim that there is no basic dissimilarity between them and Russian Orthodox Christians. Differences in practices are not considered essential. Also, the Don evangelicals even attempt to adapt to local traditions in their ritualistic behaviour.

For example, they have arranged the commemoration of a deceased congregation member in the local graveyard, which could be interpreted as an attempt to fit into the Orthodox social environment. The Protestants did not copy all related Orthodox customs but just sang the departed lady's favourite songs. 
More evidence has been recorded concerning a spiritual dialogue or amalgamation. In the Don evangelical community there are some women who have been baptised by ROC priests (one of these elderly women even after having visited Protestant meetings regularly during 3 years). 'Grannies' also bring folk Orthodox rituality into Don evangelical church (for example, in August 2011, when celebrating the Transfiguration ${ }^{15}$ by bringing some apples to the afterservice meal and disappointing the evangelical missionary Semyon greatly when they were not really able to answer what kind of holiday they were celebrating and why, and what it had to do with apples).

In general, the evangelical community of Don favours a very tolerant approach to the local population's religious habits - as long as they are not seen as purely hypocritical or diverting from the genuine relationship with God - and attempts to fit in with the overall Orthodox social context.

\section{DISCUSSION}

Although the Orthodox community of the Kulömdin area is not coherent in its understanding of faith, there are no basic differences in its attitude towards the Don evangelicals. Common features of this standpoint can be summed up with a couple of general notions.

First, an overwhelming majority of the local population with an Orthodox background (regardless of the degree of their own religious activism) considers Protestants as a kind of peripheral social phenomenon. Protestantism is treated as a deviation from normality in the sense of spiritual practice and considered to be a little dangerous to Komi traditions and overall Kominess, despite the fact that Protestants constitute just a tiny minority in Kulömdin district. ${ }^{16} \mathrm{At}$ the same time, the topic of Protestant appearance and growth in the region is not actively discussed among the people of Kulömdin district. For example, only a few people have noticed that Pentecostals act in the district centre, although they have been present since 2000. Meanwhile, the Don evangelicals are relatively well-known, although mainly because they had an American missionary among them for 7 years. Actually, this topic leads us to the next point.

According to the common understanding of the population of Kulömdin district, Protestantism is initiated and nurtured by Others (predominately, Americans). This means that people presume the existence of a certain political agenda, which is hidden behind the public message of the Protestant mission.

Sometimes more ambivalent or neutral opinions have been expressed, stressing that any sincere spiritual effort is welcomed. Initially, the Orthodox priest of Kulömdin church also accepted the Don evangelicals' efforts in spreading the 
Christian message and joint services were even held. ${ }^{17}$ Later, this relatively friendly co-operation ceased. Members of Don evangelical community argue that an ideological line in the diocese of the local Russian Orthodox Church tightened and priest Alexander was forced to break off his closer contacts with local Protestants. Father Alexander explained his unwillingness to have too familiar a relationship with evangelical Christians by Protestants' excessive eagerness to publicly demonstrate the sameness of the evangelical and Russian Orthodox faith.

Unexpectedly for the Orthodox majority, but with clear pragmatic logic, Protestants react to this rejection by introducing an ideology of reason, similarity and normality. Protestants assert that 'the real faith' is the same among all Christians and everyone needs to co-operate in evangelisation. Evangelicals also claim that they accomplish missionary tasks similarly to original Orthodox enlighteners, applying the Komi language in spreading God's message. In this way Protestants revive authentic local missionary practices. Missionary William is metaphorically domesticated by being equated with St Stephan of Perm.

This kind of flexible and fast adaptation to the local cultural context by using the most unexpected arguments has been documented in respect of evangelical churches in different countries (see, for example, Lunkin 2009: 97, 112).

It must be admitted that for the majority of the population in Kulömdin district, this effort of presenting evangelical faith as in principle identical and equal to Russian Orthodoxy has remained largely unnoticed. People do not delve into evangelicals' efforts to settle with local spiritual traditions. Instead, they may discuss the issue that the local Orthodox bishop Pitirim also claims to carry on a Christian mission in the footsteps of St Stephan of Perm (FM 2010). ${ }^{18}$

Finally, we would like to return to the discussion of collective and individual components of contemporary Komi identity in the context of religiosity. We can assert that individual understandings and expectations exist concerning collective values. Strictly speaking, it is impossible to detect a definite collective subject. At the same time, there are certain similarities in individual attitudes that produce an impression of a considerable impact from collectivism on individual life philosophies and behavioural patterns.

We can deduce from Cohen's as well as Hogg and Reid's approaches that a theoretical problem exists concerning the complex, variable and plastic nature of the self (both individual and collective). As our field experience indicates, collectivism is highly valued among Komi villagers irrespective of their religious preferences; meanwhile the actual details of collective values may be interpreted individually. People are convinced that they share a certain set of ideals with other members of the community, although sometimes these mean different things. 
Further, it must be noticed that in an intergroup relationship, different models of communication have a contradictory but to some extent also somewhat logical pattern. The sense of sameness is not always defined by confessional boundaries. Don evangelicals are ready to associate themselves (due to similarities in the genuineness of the faith) with local Russian Orthodox churchgoers (but not with the majority of local population with loose Orthodox identity). However, Protestants' suspected foreign ethnic agenda hinders a possible association between these groups from the Komi Orthodox point of view.

It is usually possible to pick out a number of contradictory details from one's field data. In any case, these modalities indicate that two tendencies exist simultaneously. On the one hand, there is an ambivalent interpretation of group characteristics and values, even those that are considered central. There is no grass-roots level conformity in the details of understanding a group's practice and ideology. On the other hand, collectivism exists as an in-group perceptual idea, and this too is a firm fact.

\section{ABBREVIATIONS}

FM = fieldwork materials of the authors from 2006-2011

\section{NOTES}

1 This research was supported by the European Union through the European Regional Development Fund (Centre of Excellence, CECT), Estonian Science Foundation (Grant No. 8335) and the Center for the Study of Pentecostal and Charismatic Movements in Russia.

2 The Komis (Komi-Zyryans) are a Finno-Ugric people with a population of 228,235 according to the Russian census carried out in 2010 (Perepis: online). The Komi Republic is situated in the northeastern corner of the European part of the Russian Federation.

${ }^{3}$ Art Leete has been visiting the area annually since 1996, Piret Koosa started her fieldwork among the Komis in 2006.

4 This statement was made during a discussion about Komi ethnographic groups (the Izhma and Udora Komi) that had declared their will to be recognised as separate ethnic units, not as a part of the Komi people.

${ }^{5}$ It is interesting to mention that the official website of Kulömdin district (Kulömdin culture: online) introduces Kulömdin as "one of the main keepers of Komi ethnic traditions and culture". It is also notable that in 1926 a discussion was initiated in the local newspaper Yugyd Tuy concerning a plan to transfer the capital of the Komi region 
from Ust-Sysolsk (today Syktyvkar) to Kulömdin: "Only Kulömdin unites the whole land into a whole, only Kulömdin consolidates around itself all parts of Komiland" (Zherebtsov et al. 2007: 160).

6 The initial leader of the Bursylysyas translated ritual Orthodox texts into Komi. He also delivered his own sermons, translated several psalms into the Komi language, wrote religious hymns and organised spiritual conversations in Komi. The movement still exists today. (For more about the Bursylysyas movement, see Chuvyurov \& Smirnova 2003; Koosa \& Leete 2011.)

7 Local evangelicals usually call themselves simply Christians.

8 Grannies (babushki in Russian) - old religious women who formerly, before Soviet repressions, took charge of the religious rituals conducted by Orthodox priests. These elderly women are still widely acknowledged as religious experts among the community. It even happens that to some people their opinion in matters relating to religion has more authority than that of the local priests (Mitrokhin 2006: 45; Keinänen 1999: 159). The term is widely used in Russian scholarly literature and everyday conversation.

9 This woman refers to the American evangelical missionary William Wood (who himself belongs to a nondenominational church), who sees his mission in spreading the word of God in the Russian North. In 2004, he played a crucial role in establishing an evangelical community in Don village, Kulömdin. In 2011, William left the Don group and initiated a new evangelical community in Koigorodok village in the southwestern part of the Republic of Komi.

${ }^{10}$ In 1866, the monastery of the Holy Trinity and St Stephan was established in Ulyanovo, at a distance of 25 kilometres from Kulömdin. At the monastery, several churches were opened between 1867 and 1886. By the end of 1918 the monastery was closed. In 1994, a group of monks lead by Father Superior Pitirim (later the bishop) re-established the monastery. (Rogachev 2001: 73, 75, 80; Taskaev 2001: 85-94)

${ }^{11}$ At the same time, quite a few villagers react with annoyance when William, as a former drug addict, is presented to them as almost a holy man, and feel that he is not the right person to judge their way of life and preach the word of God to them.

12 The Don evangelical community consists of around 15 more or less regular members (almost exclusively women - by 2011, the last male church-goer left the group and the only men around are missionaries), most of them Komis.

${ }^{13}$ A Baptist church in Syktyvkar.

${ }^{14}$ Komi Protestants have a deep interest in this topic. For example, Nadezhda Popova from the Komi Evangelical Church has completed her BA studies at the Baltic Methodist Theological Seminary with a study of the mission practice of St Stephan of Perm (see Popova 2009).

15 Transfiguration (in Russian: Preobrazheniye Gospoda Boga i Spasa nashego Iisusa Hrista, August 19th) in official church tradition (see Matthew 17:1-9; Mark 9:2-10; Luke 9:28-36). In Komi folk traditions (in accordance with customs in all Russian 
Orthodox regions), at Transfiguration people bring to the church apples and other fruits and berries, which are blessed after the service (Konakov 1993: 96-97).

${ }^{16}$ We once asked pastor Andrei how many Protestants there were in Kulömdin district. He replied: "Protestants? You can just count them on your fingers." By using this method, Andrei managed to number 50 active believers and up to 100 'leavers' ( $u k$ hozhane in Russian, as Andrei said), i.e., those, who have visited Protestant meetings but have not become (regular) visitors (FM 2009). This means that, depending on the mode of calculation, Protestants constitute $0.17-0.5 \%$ of the district's population. (No official statistics concerning Protestants in the area are available. Therefore, one must just ask somebody who knows them all.)

17 The Don evangelical community was founded in 2004, and Father Alexander started his services in Kulömdin Orthodox church in the autumn season of 2006 (before that for 3 years there was no permanent Orthodox priest in Kulömdin and monks from nearby Ulyanovo monastery performed more or less regular church rituals). By the spring of 2007, the relationship between these two congregations had already worsened.

${ }^{18}$ Pitirim even managed to give an anti-Protestant speech in Don middle school (although religious propaganda is prohibited in schools). This fact demonstrates that the ROC takes William's efforts very seriously. In addition, over the last couple of years, priest Alexander has arranged Russian Orthodox ceremonies in a private house in Don village (Sizov 2009). And the next Orthodox church in Kulömdin district will soon be built in Don.

In the mid-1990s, the idea of the metaphorical return of St Stephan of Perm was firmly present in Komi national discourse (see, for example, Vasse-Vásolyi 1996: 46).

\section{REFERENCES}

Arsenyev, Flegont A. 2010 [1873]. Zyriane i ikh okhotnich'i promysly. [The Zyryans and Their Hunting Practices.] In: V. A. Limerova (ed.) Zyriane i zyrianskii krai v literaturnykh dokumentakh XIX veka. [The Zyryans and Zyryan Land in the Literary Documents of the 19th Century.] Syktyvkar: OOO Izdatel'stvo Kola, pp. 42-52.

Chernetsov, A. V. 1996. Stefan Permskii: istoriia i legenda. [Stephan of Perm: History and Legend.] In: Khristianizatsija Komi kraia i ee rol'v razvitii gosudarstvennosti $i$ kul'tury. [Christianisation of Komi Land and its Role in the Development of Statehood and Culture.] Tom 1. Plenarnye doklady. Istoriia. Syktyvkar: Komi nauchnyi tsentr UrO RAN, pp. 34-39.

Chuvyurov, Alexander \& Smirnova, Olga 2003. Confessional Factor in the Ethno-Cultural Processes of the Upper-Vychegda Komi. Pro Ethnologia 15, pp. 169-196.

Cohen, Anthony P. 1995. Self Consciousness: An Alternative Anthropology of Identity. London \& New York: Routledge.

Durkheim, Émile 1995 [1912]. The Elementary Forms of the Religious Life. New York [etc]: The Free Press. 
Episkop Pitirim Syktyvkarskii i Vorkutinskii 1996. Vosstanovlenie samostoiatel'noi eparkhii i vozrozhdenie pravoslavnoi zhizni na territorii Komi kraia k 1996 godu. [Establishing the Independent Diocese and Revitalising Orthodox Life on the Territory of Komi Land by 1996.] In: Khristianizatsiia Komi kraia i ee rol'v razvitii gosudarstvennosti $i$ kul'tury. [Christianisation of Komi Land and its Role in the Development of Statehood and Culture.] Tom 1. Plenarnye doklady. Istoriia. Syktyvkar: Komi nauchnyi tsentr UrO RAN, pp. 28-33.

Episkop Pitirim Syktyvkarskii i Vorkutinskii 2010. Zaiavlenie. [Statement.] http://syktyvkar.eparchia.ru/slovo.html, last accessed on 22 November 2011.

Geertz, Clifford 1993 [1983]. Local Knowledge: Further Essays in Interpretive Anthropology. London: Fontana Press.

Gross, Toomas 2008. Religiooniantropoloogia. [Anthropology of Religion.] Keel ja Kirjandus 8-9, pp. 641-653.

Hicks, David 1999. Introduction. In: David Hicks (ed.) Ritual and Belief: Readings in the Anthropology of Religion. Boston [etc.]: McGraw-Hill College, pp. xvii-xxv.

Hogg, Michael A. \& Reid, Scott A. 2006. Social Identity, Self-Categorization, and the Communication of Group Norms. Communication Theory, Vol. 16, pp. 7-30, doi:10.1111/j.1468-2885.2006.00003.x.

Jääts, Indrek 2005. Etnilised protsessid Vene impeeriumi siseperifeerias 1801-1904. Komi rahvusluse sünd. [Ethnic Processes in Inner Periphery of Russian Empire 1801-1904. The Birth of Komi Nationalism.] PhD thesis. Tartu: Tartu University Press.

Keinänen, Marja-Liisa 1999. Some Remarks on Women's Religious Traditionalism in the Rural Soviet Karelia. Studies in Folklore and Popular Religion, Vol. 2, pp. 153-172.

Konakov, Nikolai Dmitrievich 1993. Ot sviatok do sochel'nika: Komi traditsionnye kalendarnye obriady. [From Christmastide to Christmas Eve: Komi Traditional Calendar Rituals.] Syktyvkar: Komi knizhnoe izdatel'stvo.

Koosa, Piret 2010. Öigeusk kaasaegses komi külas. [Orthodoxy in Contemporary Komi Village.] Studia Ethnologica et Folkloristica Tartuensia 12. Tartu: Tartu Ülikooli Kirjastus.

Koosa, Piret \& Leete, Art 2011. Revolt of Grannies: The Bursylysyas Komi Folk Orthodox Movement. Journal of Ethnology and Folkloristics 5(1), pp. 45-61.

Kulömdin culture: online = Ust'-Kulomskii raion. Kul"tura. http://www.ust-kulom.parma. ru/modules/about/article.php?articleid=3, last accessed on 11 January 2009.

Leete, Art 2011. "We are not skilled in faith". Religious change among the Komis. El Pais 22.07.2011. http://www.elpais.com/articulo/cultura/We/are/not/skilled/in/ faith/Religious/change/among/the/Komis/elpepucul/20110722elpepucul_17/Tes, last accessed on 3 October 2011.

Limerov, Pavel 2003. Christian Images in Komi Mythology. In: Nikolai Konakov \& Vladimir Napolskikh \& Anna-Leena Siikala \& Mihály Hoppál (eds.) The Encyclopaedia of Uralic Mythologies. Volume I. Komi Mythology. Budapest: Akadémiai Kiadó; Helsinki: Finnish Literature Society, pp. 63-65. 
Lunkin, Roman 2009. Protestantizm i globalizatsiia na prostorakh Evrazii. [Protestantism and Globalisation on the Expanses of Eurasia.] In: Aleksei Malashenko \& Sergei Filatov (eds.) Religiia $i$ globalizatsiia na prostorakh Evrazii. [Religion and Globalisation on the Expanses of Eurasia.] Moskva: ROSSPEN, Moskovskii Tsentr Karnegi, pp. 91-125.

Meyer, Birgit 2010. Pentecostalism and Globalization. In: Allan Anderson \& Michael Bergunder \& André Droogers \& Cornelis van der Laan (eds.) Studying Global Pentecostalism: Theories and Methods. University of California Press, pp. 113-130.

Mikhailov, M. I. 2010 [1851]. Promysly zyrian Ust'sysol'skogo i Iarenskogo uezdov Vologodskoi gubernii. [Subsistence Patterns of the Zyryans of Ust'-Sysolsk and Yarensk Counties of Vologda Guberniya.] In: V. A. Limerova (ed.) Zyriane i zyrianskii krai v literaturnykh dokumentakh XIX veka. [The Zyryans and Zyryan Land in the Literary Documents of the 19th Century.] Syktyvkar: OOO Izdatel'stvo Kola, pp. 21-23.

Mikhailov, M. I. 2010 [1852]. O zemledelii i skotovodstve u zyrian Ust'sysol'skogo uezda. [About Agriculture and Cattle-Breeding among the Zyryans of Ust'-Sysolsk County.] In: V. A. Limerova (ed.) Zyriane i zyrianskii krai v literaturnykh dokumentakh XIX veka. [The Zyryans and Zyryan Land in the Literary Documents of the 19th Century.] Syktyvkar: OOO Izdatel'stvo Kola, pp. 25-30.

Mitrokhin, Nikolai 2006. Russkaia pravoslavnaia tserkov': sovremennoe sostoianie i aktual'nye problemy. [The Russian Orthodox Church: Contemporary Situation and Topical Problems.] Moskva: Novoe literaturnoe obozrenie.

Panchenko, Alexander 2004. New Religious Movements and the Study of Folklore: The Russian Case. Folklore: Electronic Journal of Folklore, Vol. 28, pp. 111-128.

Perepis'. [Census.] http://www.gks.ru/free_doc/new_site/perepis2010/perepis_itogi1612. htm, last accessed on 23 June 2012.

Popov, Klavdii A. 1874. Zyriane i zyrianskii krai. [The Zyryans and Zyryan Land.] In: Izvestiia Imperatorskago Obshchestva liubitelei estestvoznaniia, antropologii $i$ etnografii. [Notes of the Imperial Society of the Friends of Natural Science, Anthropology and Ethnography.] Tom XIII, vypusk 2-oi. Trudy etnograficheskago otdela, Kniga 3, Vypusk 2. Moskva: Obshchestvo.

Popova, Nadezhda 2009. Missionerskaia deiatel'nost'Stefana Permskogo na Komi zemle i ee rol'v kontekste istorii. [Missionary Activities of Stephan of Perm in the Komi Land and their Role in the Context of History.] Graduation thesis. Tallinn: Teologicheskaia seminariia EMTs (manuscript).

Robbins, Joel 2004. The Globalization of Pentecostal and Charismatic Christianity. Annual Review of Anthropology, Vol. 33, pp. 117-143, doi:10.1146/annurev.anthro.32.061002.093421.

Robbins, Joel 2010. Anthropology, Pentecostalism, and the New Paul: Conversion, Event, and Social Transformation. South Atlantic Quarterly, Vol. 109 (4), pp. 633-652, doi:10.1215/00382876-2010-010.

Rogachev, Mikhail 2001. “Tserkov'v kazhdoi derevne vozvyshalas' nad vsemi drugimi stroeniiami” (khramy Komi kraia v XIV-XX vv.). [“The Church Towered over all the Other Buildings in Every Village" (Shrines of Komi Land during the 19th and 
20th Centuries).] In: Nikolai Dmitrievich Konakov (comp. \& ed.) Khristianstvo $i$ iazychestvo naroda Komi. [Christianity and Paganism of the Komi People.] Syktyvkar: Komi knizhnoe izdatel'stvo, pp. 64-82.

Savelyeva, Eleanora A. 2004. Arkhaichnye obshchestva na territorii Komi kraia. [Archaic Societies on the Territory of Komi Land.] In: Istoriia Komi s drevneishikh vremen do kontsa XX veka. [Komi History from the Earliest Times until the End of the 20th Century.] T. 1. Syktyvkar: Komi knizhnoe izdatel'stvo, pp. 15-61.

Shterin, Marat 2000. New Religious Movements in Russia in the 1990s. In: Matti Kotiranta (ed.) Religious Transition in Russia. Helsinki: Kikimora Publications, pp. 175-184.

Sidorov, Aleksei Semenovich 1997 [1928]. Znakharstvo, koldovstvo n porcha u naroda komi. [Folk Healing, Magic and Witchcraft among the Komi People.] SanktPeterburg: Izdatel'stvo "Aleteiia”.

Sizov, M. 2009. Voda iz kolodtsa: Moroznyi denek v sel'skoi glubinke [Water from a Well: Cold Day in Remote Countryside.] Vera-Eskom 582. http://www.rusvera. mrezha.ru/582/5.htm, last accessed on 11 November 2011.

Stark, Laura 2002. Peasants, pilgrims, and sacred promises: ritual and supernatural in Orthodox Karelian folk religion. Studia Fennica. Folkloristica, 11. Helsinki: Finnish Literature Society.

Suvorov, E. 2007. Dve radugi v vide kresta. [Two Rainbows in the Form of a Cross.] Vera-Eskom 548. http://www.rusvera.mrezha.ru/548/8.htm, last accessed on 11 November 2011.

Taskaev, Mikhail 2001. Ul'ianovskaii monastyr' (istoricheskaia spravka). [Ulyanovo Monastery (a Historical Note).] In: Nikolai Dmitrievich Konakov (comp. \& ed.) Khristianstvo i iazychestvo naroda Komi. [Christianity and Paganism of the Komi People.] Syktyvkar: Komi knizhnoe izdatel'stvo, pp. 83-95.

Vasse-Vásolyi, E. G. 1996. Orthodox Christianity and Russian Colonialism: The Komi Experience in an International Perspective. In: Khristianizatsiia Komi kraia i ee rol'v razvitii gosudarstvennosti $i$ kul'tury. [Christianisation of Komi Land and its Role in the Development of Statehood and Culture.] Tom 1. Plenarnye doklady. Istoriia. Syktyvkar: Komi nauchnyi tsentr UrO RAN, pp. 40-46.

Vedernikova, Olga V. 1996. Osmyslenie khristianizatsii v komi fol'klore. [Conceptualising of Christianisation in Komi Folklore.] In: Khristianizatsiia Komi kraia i ee rol'v razvitii gosudarstvennosti i kul'tury. [Christianisation of Komi Land and its Role in the Development of Statehood and Culture.] Tom II. Filologiia. Etnologiia. Syktyvkar: Komi nauchnyi tsentr UrO RAN, pp. 37-42.

Vlasova, Viktoriia Vladimirovna 2010. Staroobriadcheskie gruppy komi: konfessional'nye osobennosti sotsial'noi i obriadovoi zhizni. [Groups of Komi Old-Believers: Confessional Features of Social and Ritual Life.] Syktyvkar: Komi nauchnyi tsentr UrO RAN.

Volkov, N. D. 2010 [1879]. Udorskii krai. (Etnograficheskii ocherk). [Udora Land. (Ethnographical Essay).] In: V. A. Limerova (ed.) Zyriane $i$ zyrianskii krai v literaturnykh dokumentakh XIX veka. [The Zyryans and Zyryan Land in the Literary Documents of the 19th Century.] Syktyvkar: OOO Izdatel'stvo Kola, pp. 53-68. 
Zherebtsov, Liubomir Nikolaevich \& Zherebtsov, Igor' Liubomirovich 2004. Kul'tura naroda komi v XV-XVII vekakh. [Culture of the Komi People in the 15th-17th Centuries.] In: Istoriia Komi s drevneishikh vremen do kontsa XX veka. [Komi History from the Earliest Times until the End of the 20th Century.] T. 1. Syktyvkar: Komi knizhnoe izdatel'stvo, pp. 204-217.

Zherebtsov, I. L. \& Taskaev, M. V. \& Rogachev, M. B. \& Kolegov, B. R. 2007. Sviaz' vremen: Istoriia Respubliki Komi v litsakh $i$ datakh. [Connection of Times: History of the Republic of Komi in People and Dates.] Syktyvkar (CD-ROM). 